\title{
Earthworm invasion into previously earthworm-free temperate and boreal forests
}

\author{
Lee E. Frelich • Cindy M. Hale - Stefan Scheu • \\ Andrew R. Holdsworth · Liam Heneghan · \\ Patrick J. Bohlen · Peter B. Reich
}

Published online: 4 July 2006

(C) Springer Science+Business Media B.V. 2006

\begin{abstract}
Earthworms are keystone detritivores that can influence primary producers by changing seedbed conditions, soil characteristics, flow of water, nutrients and carbon, and plant-herbivore interactions. The invasion of European earthworms into previously earthworm-free temperate and boreal forests of North America dominated by Acer, Quercus, Betula, Pinus and Populus has provided ample opportunity to observe how earthworms engineer ecosystems. Impacts vary
\end{abstract}

L. E. Frelich $(\bowtie) \cdot$ C. M. Hale ·

A. R. Holdsworth · P. B. Reich

Department of Forest Resources, University of Minnesota, 1530 Cleveland Ave. N., St. Paul, MN 55108, USA

e-mail: freli001@umn.edu

C. M. Hale

Natural Resources Research Institute, University of Minnesota-Duluth, 5013 Miller Trunk Highway, Duluth, MN 55811, USA

S. Scheu

Institut für Zoologie, Technische Universität Darmstadt, Schnittspahnstraße 3, 64287 Darmstadt, Germany

\section{Heneghan}

Environmental Science Program, DePaul University, 2325 Clifton Ave., Chicago, IL 60614-3207, USA

P. J. Bohlen

Archbold Biological Station, Lake Placid, Florida 33852, USA with soil parent material, land use history, and assemblage of invading earthworm species. Earthworms reduce the thickness of organic layers, increase the bulk density of soils and incorporate litter and humus materials into deeper horizons of the soil profile, thereby affecting the whole soil food web and the above ground plant community. Mixing of organic and mineral materials turns mor into mull humus which significantly changes the distribution and community composition of the soil microflora and seedbed conditions for vascular plants. In some forests earthworm invasion leads to reduced availability and increased leaching of $\mathrm{N}$ and $\mathrm{P}$ in soil horizons where most fine roots are concentrated. Earthworms can contribute to a forest decline syndrome, and forest herbs in the genera Aralia, Botrychium, Osmorhiza, Trillium, Uvularia, and Viola are reduced in abundance during earthworm invasion. The degree of plant recovery after invasion varies greatly among sites and depends on complex interactions with soil processes and herbivores. These changes are likely to alter competitive relationships among plant species, possibly facilitating invasion of exotic plant species such as Rhamnus cathartica into North American forests, leading to as yet unknown changes in successional trajectory.

Keywords Aporrectodea $\cdot$ Dendrobaena $\cdot$ Exotic earthworm invasion ' Lumbricus rubellus · 
Lumbricus terrestris $\cdot$ Keystone species ·

Minnesota forests $\cdot$ New York forests

\section{Introduction}

Invasion by non-native earthworms into previously earthworm-free forest ecosystems has only recently received substantial attention from ecologists. Such ecosystems occur in the temperate and cold-temperate deciduous and mixed deciduous-conifer forests of North America at latitudes of $45-60^{\circ} \mathrm{N}$, an area of several million $\mathrm{km}^{2}$. Earthworms native to North America were unknown in this region prior to the introduction of European earthworm species (Lumbricidae) that started in the 1700s and continues today (see Tiunov et al. this issue).

Because earthworms are ecosystem engineers (sensu Jones et al. 1994) that change basic processes such as cycling and movement of water and nutrients, soil structure, and seedbed conditions, their introduction causes profound effects that cascade throughout ecosystems. Earthworms are part of the detritivore community, consuming leaf litter and increasing rates of decomposition. Although it is well known that detritivores and decomposers are necessary for recycling of carbon and nutrients, seldom do scientists have the chance to observe how a major change in the detritivore community affects ecosystems at large spatial scales, as is occurring now with European earthworm invasion in cold-temperate forests. In this paper we review the evidence that earthworms engineer forest ecosystems to the extent that they can be considered a keystone class of organisms that exert control over many aspects of ecosystem structure and function, including the primary producers.

There is a vast scientific literature on earthworm ecology in areas where they are native, and on impacts of exotic earthworms on agricultural systems (Lee 1985; Edwards and Bohlen 1995; Edwards 2004). However, there is little published on the impacts of earthworms on native plants (Scheu 2003). The study of impacts of exotic earthworm species on native soils devoid of earthworms and on the response of native soil food webs and native plant species within these ecosystems is a very recent phenomenon (Parkinson et al. 2004; Bohlen et al. 2004a, b).

The overall objective of this paper is to examine impacts of exotic earthworm introduction on soils and plant communities in a large region that was previously devoid of earthworms. Three major topics are addressed: (1) changes in soil structure and processes caused by exotic earthworms; (2) potential mechanisms by which earthworms influence the soil and plant community and the long-term changes expected; and (3) the current evidence for these mechanisms. Finally, avenues of future research are proposed.

\section{Impacts on soils}

Upon invasion, earthworms alter the structure of soil horizons, availability of nutrients, and soil biota. The type and magnitude of these impacts vary with the species of earthworm and characteristics of the soil. Colonization by litter-dwelling, epigeic earthworm species such as Dendrobaena octaedra physically disrupts the separation of organic layers by mixing of $\mathrm{F}\left(\mathrm{O}_{\mathrm{e}}\right)$ and $\mathrm{H}\left(\mathrm{O}_{\mathrm{a}}\right)$ materials, but leaves the litter $(\mathrm{L}$ or $\mathrm{O}_{\mathrm{i}}$ ) layer relatively intact and has little impact on the structure of the mineral soil (McLean and Parkinson 1997a, b). Soil dwelling endogeic, epiendogeic and deep-burrowing anecic earthworm species (e.g. Aporrectodea sp., Lumbricus rubellus, and L. terrestris, respectively) consume the surface organic horizon, mixing surface litter into the upper mineral soil horizons, to an average depth of $25-30 \mathrm{~cm}$ (Lee 1985; Edwards and Bohlen 1995). Therefore, the result of multi-species earthworm invasion is conversion from a mor organic horizon structure (consisting of $\mathrm{O}_{\mathrm{i}}, \mathrm{O}_{\mathrm{e}}, \mathrm{O}_{\mathrm{a}}$ subhorizons) over a thin A horizon and welldeveloped $\mathrm{E}$ horizon below, to a mull structure similar to a previously farmed plow layer (only $\mathrm{O}_{\mathrm{i}}$ subhorizon present) over a relatively deep (up to $25 \mathrm{~cm}$ ) organic-rich A horizon (Langmaid 1964; Shaw and Pawluk 1986; Alban and Berry 1994). This post-earthworm structure is similar to soils found under non-acid hardwood forests in northern Europe, where the lumbricid species of earthworms invading North America are native (Kubiena 1948; Bal 1982; Ponge and Delhaye 1995). 
Earthworm-free forest soils that have not been previously plowed by humans tend to have very low bulk densities, due to the presence of a thick litter layer and the burrowing action of many species of native invertebrates (McLean and Parkinson 1997a; Bohlen et al. 2004a). The introduction of earthworms increases bulk density by decreasing the thickness of the forest floor, reducing the abundance of native soil dwelling invertebrate species, and cementing soil particles together during burrowing and casting activities (McLean and Parkinson 1998a, b; Scheu and Parkinson 1994a; Alban and Berry 1994; Migge 2001). Although a soil fauna community typical for deciduous mull humus forests in Europe can lead to relatively low bulk densities in the presence of earthworms (Bal 1982; Schaefer 1991), it is unknown whether such adjustments in the soil fauna will lead to recovery of low bulk densities in recently invaded North American forests.

Earthworms strongly affect soil nutrient availability either directly via soil processing or indirectly via changes in the microbial and soil invertebrate community, but exotic earthworm invasions have variable effects on nutrient availability. Laboratory and field microcosm studies have shown increased nutrient availability and plant growth with the presence of earthworms (Scheu 1987; Scheu and Parkinson 1994a, b). Many of the laboratory studies compared earthworm casting material to the surrounding soil, or were done over short time periods (e.g. Lunt and Jacobsen 1944; Syers et al. 1979; Parkin and Berry 1994). It is unclear how applicable these results are to larger spatial and temporal scales. Nutrients mobilized during the rapid incorporation of a multi-year accumulation of surface litter during initial earthworm invasion may ultimately be immobilized or leached out of the ecosystem.

Field studies have shown variable effects of earthworm invasion on soil $\mathrm{N}$ dynamics. Invasion of maple forests in New York by Lumbricus spp. increased leaching of $\mathrm{NO}_{3}$ in a historically plowed site, but not at another site that had never been plowed, possibly because of the greater potential for $\mathrm{N}$ immobilization in the more C-rich unplowed site. Total soil $\mathrm{N}$ was not significantly changed by earthworm invasion (Bohlen et al. 2004c). Nitrogen availability in the A horizon declined after multiple-species earthworm invasion in Minnesota hardwood forests (Hale et al. 2005a).

Phosphorous is more easily leached from ecosystems when European earthworms invade. Suarez et al. (2004) found an increase in P leaching and decrease in $\mathrm{P}$ availability on plots in a New York sugar maple forest dominated by $L$. rubellus. Although phosphorous availability in upper soil horizons increased in plots with L. terrestris, presumably because $L$. terrestris brought mineral soil from deeper horizons to the surface where it could be weathered, a net leaching loss of $\mathrm{P}$ from the ecosystem is still expected. Some soils lack sufficient unweathered $\mathrm{P}$ to maintain $\mathrm{P}$ availability despite leaching losses, and L. terrestris activity may result in lower availability as well as net leaching in some soils. Sugar maple forests in Minnesota invaded by several species including L. terrestris and L. rubellus had lower P availability than control plots without those earthworm species (Hale et al. 2005a). Loss of $\mathrm{P}$ with exotic earthworm invasion has been associated with instances of maple decline in Quebec, Canada (Paré and Bernier 1989). Absorption of $\mathrm{P}$ by tree roots through mycorrhizae hyphal networks may also be reduced when earthworms disrupt the hyphal network and reduce infection rates on tree roots (Lawrence et al. 2003).

The magnitude of earthworm invasion impacts on forest soils depends on the species assemblage of earthworms that invade as well as on land-use history. For example, strictly epigeic species, such as Dendrobaena octaedra, have minor impacts on soil physical structure, $\mathrm{C}$ distribution, bulk density, and nutrient status (McLean and Parkinson 1997a, b). The impacts to these soil characteristics are greatest when earthworm species of all ecological groups invade in concert (Hale et al. 2005a). Cultural history is also important, and impacts of earthworms may be minimal in areas that were previously plowed by humans (Bohlen et al. 2004a), presumably because cultivation mimics changes caused by earthworms, such as disrupting the forest floor and incorporating the organic horizon into the mineral soil, decreasing soil organic matter and increasing bulk density.

The abundance and diversity of earthworms that invade a given ecosystem depends on the 
available source population, soil texture and moisture, soil $\mathrm{pH}$ and litter palatability. Different assemblages of earthworms are favored depending on the vector of transport and introduction (Proulx 2003). For example, fishing bait favors a broad assemblage of epigeic, endogeic and anecic species (Hale personal observations) while transport by logging truck tires may favor only small epigeic species (Dymond et al. 1997). Epigeic or epi-endogeic species that are poorly adapted to tolerate or escape dry conditions may be prevented from colonizing extremely course or dry soil types, or have restricted abundance in drier habitats. Low soil $\mathrm{pH}$ may prevent the colonization of all but a few of the small epigeic lumbricid species (Curry 1998). The chemistry of leaf litter is also important; the palatability of plant litter for earthworms increases as the $\mathrm{C}: \mathrm{N}$ ratio decreases (Hendriksen 1990). Thus, boreal forests composed of pine (Pinus sp.) and spruce (Picea sp.) on sandy and/or acidic soils are likely to be more resistant to invasion, as they have been in northern Scandinavia despite the presence of lumbricids for thousands of years. The presence of deciduous tree species with low C:N ratio litter, such as aspen (Populus sp.) and birch (Betula sp.), mixed with pine and spruce is likely to allow earthworms to inhabit a site, especially those species such as Dendrobaena octaedra that are tolerant of poor litter quality (Nordström and Rundgren 1974; Dymond et al. 1997).

\section{Impacts on plant communities}

The cumulative impact of earthworm invasion on many plant species is likely to be substantial and may result in significant changes in community composition. In uncultivated, mature sugar maple dominated forests of northern Minnesota, earthworm invasion caused significant declines in the diversity and cover of herbaceous plants and abundance of tree seedlings (Fig. 1). Diverse, lush herb communities of spikenard (Aralia racemosa), solomon's seal (Polygonatum pubescens), bellwort (Uvularia grandiflora), nodding trillium (Trillium cernuum), large-flowered trillium (Trillium grandiflorum), and goblin fern (Botrychium
Fig. 1 Conceptual diagram for changes in plant community composition caused by European earthworms in Minnesota, USA, hardwood forests. Dashed boxes and arrows indicate hypothesized processes and connections with little data at this time

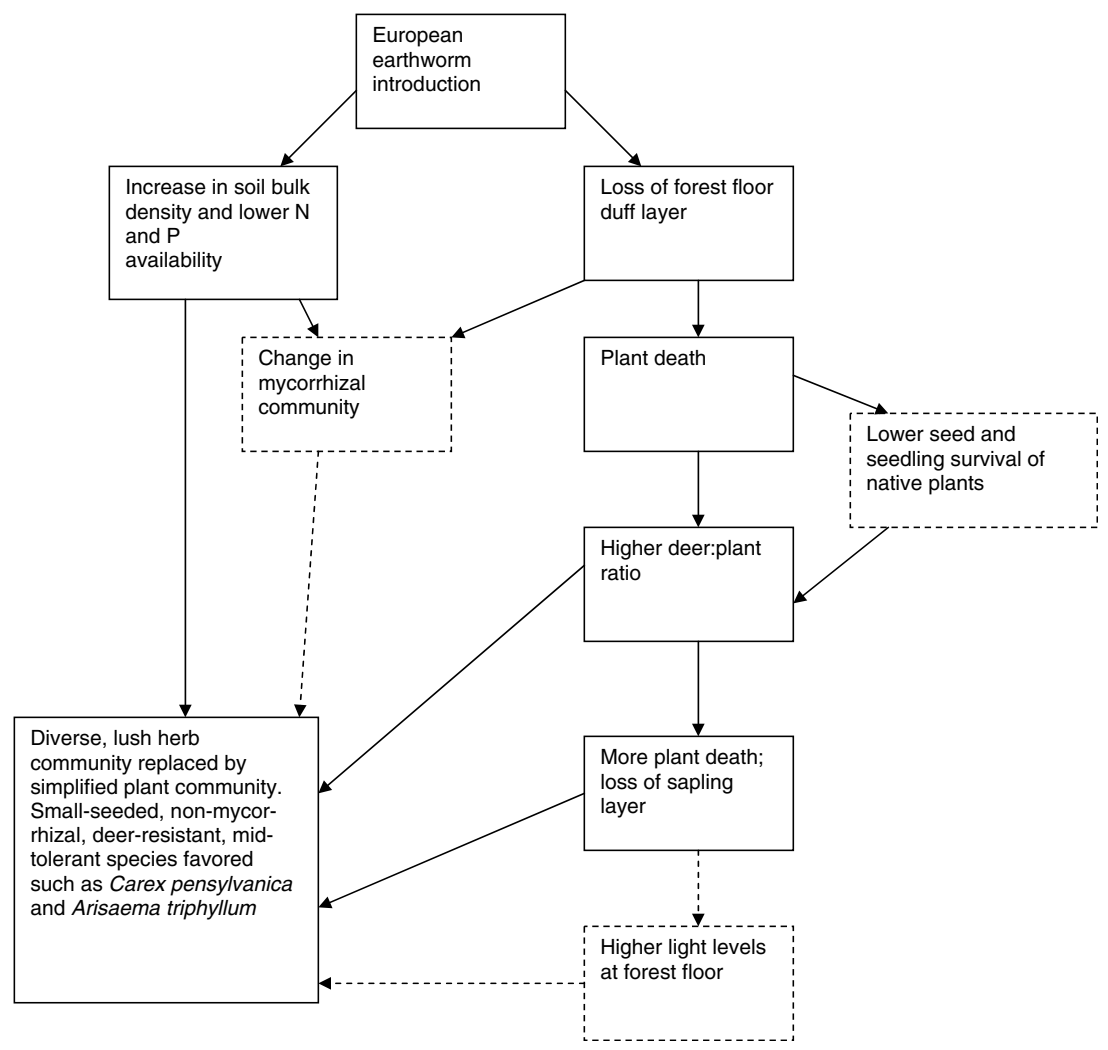


mormo) were transformed to simplified communities of only a few species dominated by Carex pennsylvanica and Arisaema triphyllum (Gundale 2002; Hale 2004) (Fig. 2). There are several possible mechanisms underlying the changes in plant communities during non-native earthworm invasion.

\section{Mechanism 1: removal of the $\mathrm{O}_{\mathrm{e}} / \mathrm{O}_{\mathrm{a}}$ horizon}

The best-known mechanism is the direct removal of the forest floor duff layer $\left(\mathrm{O}_{\mathrm{e}}\right.$ and $\mathrm{O}_{\mathrm{a}}$ horizons) by invading earthworms (Nielson and Hole 1963, 1964; Alban and Berry 1994; Bohlen et al. 2004a, c; Hale et al. 2005b). Without earthworms, temperate forests develop an organic forest floor that plays a fundamental role in nutrient cycling and serves as a seedbed and rooting zone for forest plant species. Invading earthworms cause the disappearance of the forest floor and partially or completely uproot herbs and tree seedlings (Hale
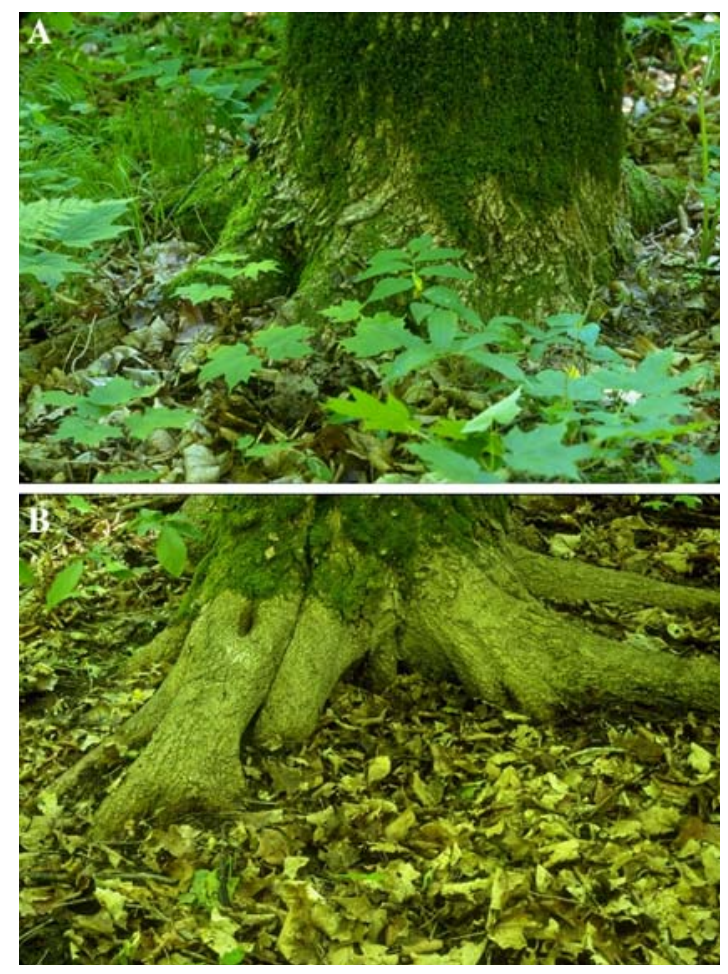

Fig. 2 Forest floor and plant community at base of trees before (a) and after (b) European earthworm invasion in a sugar maple-dominated forest on the Chippewa National Forest, Minnesota, USA. Photo credit: Dave Hansen, University of Minnesota Agricultural Experiment Station
2004). This precipitates the first round of plant mortality contributing to a forest decline syndrome (Fig. 1).

Understory plant species that succeed in forests with thick forest floors generally have larger seeds, more complex seed dormancy and germination strategies, and are more shade tolerant than plant species common to thin forest floor environments (Harper et al. 1965; Sydes and Grime 1981; Kostel-Hughes 1995; Baskin and Baskin 1998). Loss of the forest floor also reduces shelter, exposing seeds and seedlings to freezing, desiccation, and predation by insects, small mammals and other organisms (Nielsen and Hole 1964; Nixon 1995; Cothrel et al. 1997). Therefore, dramatic changes in the structure of the forest floor following earthworm invasion are expected to have a negative impact on the survival of understory species adapted to thick forest floors (Grime 1979; Gundale 2002). The thin litter layer remaining after earthworm invasion could favor the emergence of species with narrow, weak stems such as Carex species commonly found in earthworm invaded forests (Sydes and Grime 1981). We expect that species preferring a mineral soil seedbed will be favored over those preferring a duff seedbed, and that species dependent on duff, such as saprophytic coral root orchids (Corallorhiza ssp.), may be excluded or reduced in abundance following invasion.

In addition to problems with germination and emergence after earthworms change the forest floor, many of the native herbaceous species that decline during earthworm invasion are relatively poor colonizers with short seed dispersal distances (Cain et al. 1998). If nearby source populations do not exist these species are unlikely to recolonize earthworm-infested sites. For canopy tree species such as sugar maple (Acer saccharum), seed production does not appear to be affected by earthworms but seedling density clearly declines (Hale 2004).

The rate and magnitude of the removal of the forest floor and the consequences for native forest plant communities depends on the species of earthworms invading (Hale et al. 2005b). The strictly epigeic species, $D$. octaedra, has a limited effect on forest floor thickness and does not lead to increased plant mortality (Gundale 2002). 
However, a population of L. rubellus can consume $10 \mathrm{~cm}$ or more thickness of intact forest floor within one growing season, which is faster than plants rooted in the forest floor can adjust, resulting in increased plant mortality during initial invasion (Hale and Holdsworth, personal observation). In contrast, L. terrestris preferentially consumes fresh surface leaf litter rather than intact forest floor leading to a more gradual reduction of the thickness of the forest floor that may allow plants to adjust to changing conditions.

Mechanism 2: direct impact of earthworms on seeds and seedling survival

Regeneration or recovery of the understory plant community following initial earthworm invasion may be greatly affected by seed and seedling dynamics of native plants (Marquis 1975; Mladenoff 1985; Pickett and McDonnell 1989). Passage of seeds through the earthworm gut and deep burial of seeds may decrease the viability of seeds and the soil seed bank in these systems (Leck et al. 1989). For most plant species native to North American forests, little or nothing is known with regard to these impacts on seed germination.

Mechanism 3: change in the mycorrhizal community

The loss of the forest floor duff layer causes changes in the mycorrhizal community, which may indirectly contribute to simplified plant communities (Fig. 1). Changes in soil structure and chemistry and grazing by earthworms lead to changes in the abundance and structure of soil fungal communities (Johnson et al. 1992; McLean and Parkinson 1998b, 2000). The vast majority of native understory plants in northern temperate sugar maple dominated forests are strongly mycorrhizal (Brundrett and Kendrick 1988), and declines in abundance or colonization rates of mycorrhizal fungi or shifts in fungal community composition could lead to changes in the understory plant community. The Goblin fern (Botrychium mormo) is strongly mycorrhizal, appears to be dependent on thick organic horizons, and has been completely extirpated in many areas invaded by earthworms (Gundale 2002). The declines in sugar maple (Acer saccharum) seedlings during earthworm invasion (Hale 2004) could be partially due to reduced arbuscular mycorrhizal colonization rates (Lawrence et al. 2003). Plants that are non-mycorrhizal and have an extended root growth period may be favored following earthworm invasion. In western Great Lakes hardwood forests, Carex pensylvanica increases dramatically following earthworm invasion. It is one of the only non-mycorrhizal native species in these forests and has the ability to produce roots during relatively cold periods of spring and fall (Brundrett and Kendrick 1988). Such soil influences on plant species abundance and diversity have been suggested (Newman and Reddell 1988; Francis and Read 1994; van der Heijden et al. 1998; Brussaard 1999) and are supported by the emerging research on earthworm invasions. Although there are a few mycorrhizal plant species, such as Arisaema triphyllum and Circaea lutetiana that have a positive relationship with earthworm biomass, a much larger number of plant species is negatively correlated with earthworm biomass (Hale 2004).

\section{Mechanism 4: increased deer:plant ratio}

Aboveground grazers can have large effects on plant composition and diversity, particularly large ungulates like the North American white-tailed deer (Odocoileus virginianus) (Pastor et al.1998; Horsley et al. 2003). Deer herbivory and earthworm invasion could have a synergistic effect on plant communities. The initial plant mortality resulting from the removal of the forest floor by earthworms increases the deer:plant ratio, so that deer consume a much larger proportion of plants than they would in the absence of earthworms. Shifts in the deer:plant ratio can lead to extirpation of plants, and to alternate states with lush and sparse plant communities, especially if the deer:plant ratio shifts such that annual consumption by deer is greater than annual growth among plants (Augustine et al. 1998; Côté et al. 2004;). High deer:plant ratios favor plant species that produce high levels of secondary compounds. The relative abundance of two such species, Arisaema 
triphyllum and Allium tricoccum, was unaffected by earthworms (Hale 2004), perhaps because herbivores avoid grazing them.

Mechanism 5: changes in productivity and nutrients

Changes in soil chemical composition and nutrient dynamics have been documented following earthworm invasion in previously earthworm-free soils (Scheu and Parkinson 1994a; Tomlin et al. 1995; Blair et al. 1997; Burtelow et al. 1998; Bohlen et al. 2004a, c) and will likely influence future plant communities. Increases in nitrogen and phosphorous loss due to leaching (Suárez et al. 2004) and decreased nitrogen and phosphorous availability (Bohlen et al. 2004b, Hale et al. 2005a) could reduce forest productivity and benefit some species over others.

\section{Summary and future research}

Earthworms are a keystone group of detritivores that affect composition of primary producers and ecosystem productivity by changing seedbed conditions, soil characteristics, flow of water, nutrients and carbon in ecosystems, and relationships between plants and herbivores. There is evidence that they strongly influence the composition of the herbaceous plant community. Changes in the tree seedling community attributed to exotic earthworms suggest that the composition of the tree layer will ultimately be altered as well.

The impact of earthworm invasion on ecosystem productivity in previously earthworm-free forests has not been studied at this point. However, reduced availability of key nutrients such as $\mathrm{N}$ and $\mathrm{P}$, increased soil bulk density, and reduced diversity of the plant community could lead to reduced productivity through a cascade of ecosystem impacts. Long-term studies that follow individual tree growth and ecosystem-level measures of productivity such as litterfall and woody biomass production before and after earthworms invade will be necessary to ascertain impacts.

Because adult trees are not killed when earthworms invade, changes in successional trajectory and productivity may take decades or longer to detect. Therefore a way of dating earthworm invasion would be of value, so that impacts could be examined in stands invaded some time ago. Changes in soil chemistry caused by earthworms may create some sort of tree-ring signature, and if so this would be an ideal way to date time of invasion. Because earthworm invasion has been progressing through northern forests for a century, such a dating technique would allow the construction of a chronosequence of stands with varying time since invasion by earthworms. This in turn would greatly facilitate the investigation of slowly-developing, cascading ecosystem impacts of European earthworm invasion.

The impacts of earthworms on native forest soils are similar in some ways to plowing by humans. The mixing of forest floor material into the mineral soil to produce a $20-30 \mathrm{~cm}$ thick A horizon enriched with organic matter is similar in plowed soils and unplowed soils with earthworms. The findings of Bohlen et al. (2004a, c) are consistent with this hypothesis in that distribution of organic matter and nutrients within the soil were similar between areas with and without earthworms on a study site that was farmed and reforested, while invasion of earthworms into another location with primary soils (i.e. never plowed soils) caused large changes, making the soil similar to that found on the previously farmed site (Bohlen et al. 2004a, c). Based on historical information from New England, recovery of soils from farming takes centuries (Motzkin et al. 1996), and similar time frames for recovery would probably be required if exotic earthworms were somehow removed from these systems.

Earthworm invasion in some forests starts a forest decline syndrome that results in replacement of a lush diverse understory herb and tree seedling community with a sparse community of relatively low diversity (Figs. 1, 2). The degree to which the forest understory community declines depends on differential effects of various assemblages of invading earthworm species. These differential effects of earthworm species have two implications for impacts of invasive earthworms on native plant communities. First, the dominant earthworm species in a given area can influence the magnitude and rapidity of the invasion im- 
pacts. Lumbricus rubellus is a rapid, large impact ecosystem engineer, L. terrestris is a slow but large impact engineer, and Dendrobaena is a slow, small impact engineer of the forest floor environment. There is some empirical evidence for the ranking of impacts. Large areas have Dendrobaena as a dominant earthworm species and apparently retain high diversity and abundance of plants. On one Minnesota site dominated by $L$. terrestris several species of herbs persisted that disappeared from another site with L. rubellus (Hale 2004). Second, in areas with multiple species of earthworms invading, the order of invasion is important. If $L$. terrestris invades before $L$. rubellus, and the forest floor gradually disappears, then L. rubellus may have little additional effect if it invades later, and plants would have had time to adjust to the changing environment. The reverse order of invasion may be devastating to the plant community (Gundale 2002, Hale 2004). Experimental, controlled introductions of single earthworm species on field plots will be necessary to verify these field observations.

The forest decline syndrome may extend to more than just simplification of the understory herb community. Invasive plant species, successional trajectory of the tree canopy, and productivity may also be influenced by earthworm invasion. Whereas native plant species are negatively impacted by processes shown in Fig. 1, the spread of exotic plant species, such as European buckthorn (Rhamnus sp.) and garlic mustard (Alliaria officinalis), that are better adapted to the presence of earthworms than native plant species, may be enhanced by earthworm invasion. For instance, biomass and abundance of invasive earthworms increased in plots dominated by European buckthorn (Heneghan and Steffen, unpublished). European buckthorn produces leaf litter with a relatively low $\mathrm{C}: \mathrm{N}$ ratio which decomposes rapidly (Heneghan et al. 2002). Elevation of earthworm populations in soils dominated by buckthorn is therefore expected and this increase in population has some important functional implications. In an urban woodland where buckthorn was the dominant understory species and where earthworm activity was high, leaf litter of buckthorn was fully lost from litterbags within
2 months. Decomposition rates were lower in parts of the woodland where buckthorn was not present and earthworms were less abundant. Soils in plots containing buckthorn had higher $\% \mathrm{~N}$ and $\% \mathrm{C}$, elevated $\mathrm{pH}$ and gravimetric water content, and modified microbial communities (Heneghan et al. 2002). This combination of altered ecosystem properties resulted in a soil that may be less suitable for natives than for the propagules of invaders. In this case the reciprocal relationship between the invasive shrub and earthworms resulted in a situation where each species positively reinforced the population of the other species (Heneghan 2003).

Following earthworm invasions, the increase in soil bulk density and loss of the duff, which absorbs water during rainfall events and slowly releases it into the soil, could lead to a more xeric ecosystem. In many temperate forest ecosystems this could lead to changing dominance from mesic to dry-mesic species. Often this means transition from sugar maple and American basswood (Tilia Americana), which prefer mesic conditions, to oaks and red maple (A. rubrum) (Curtis 1959), species which cast less shade than the mesic forest species (Canham et al. 1994). Gradual depletion of the tree sapling layer caused by reduced seedling recruitment after earthworm invasion (and reinforced by deer herbivory) could lead to more light at the forest floor. If future studies do find this effect, then a group of tree species midtolerant of shade may be favored, including northern red oak (Quercus rubra), white oak $(Q$. alba), American basswood, green ash (Fraxinus pennsylvanica) and red maple. Duff thickness and deer browsing, however, may also have other effects that could negate changes in water status and light. For example, thick duff favors red oak germination and survival, whereas thin duff favors white oak (Rogers 1990; Sander 1990), so that white oak may be favored in forests with earthworms. Deer also favor red oak, ash and red maple relative to sugar maple for winter browsing, and may therefore help sugar maple maintain dominance (Beals et al. 1960).

Changes in forest composition after earthworm invasion will be complex, and will interact with other agents of global change, such as warming climate. Long-term studies that follow soil water, 
nutrients, light levels, and plant community composition inside and outside of large deer exclosures, replicated in areas with and without exotic earthworms, will be necessary to examine how the cascade of impacts starting from earthworm invasion will influence the successional trajectory of the forest. At this point it appears likely that warming climate will allow higher deer populations in northern forests as well as faster northward expansion of invading earthworm populations. Thus we can hypothesize that warmer temperatures, deer and earthworms will work synergistically to change temperate forest ecosystems much faster than any one of these factors would by itself.

Acknowledgements Funding from the National Science Foundation (DEB-0075236) and University of Minnesota Center for Hardwood Ecology is gratefully acknowledged.

\section{References}

Alban DH, Berry EC (1994) Effects of earthworm invasion on morphology, carbon, and nitrogen of a forest soil. Appl Soil Ecol 1:243-249

Augustine DJ, Frelich LE, Jordan PA (1998) Evidence for two alternate stable states in an ungulate grazing system. Ecol Appl 8:1260-1269

Bal L (1982) Zoological ripening of soils. Centre for Agricultural Publishing and Documents, Wageningen, The Netherlands

Baskin CC, Baskin JM (1998) Seeds: ecology, biogeography and evolution of dormancy and germination. Academic Press, San Diego

Beals EW, Cottam G, Vogel RJ (1960) Influence of deer on vegetation of the Apostle Islands, Wisconsin. J Wildl Manage 24:68-80

Blair JM, Parmalee RW, Allen MF, McCartney DA, Stinner BR (1997) Changes in soil N pools in response to earthworm population manipulations in agroecosystems with different $\mathrm{N}$ sources. Soil Biol Biochem 29:361-36

Bohlen PJ, Groffman PM, Fahey TJ, Fisk MC, Suarez E, Pelletier DM, Fahey RT (2004a) Ecosystem consequences of exotic earthworm invasion of north temperate forests. Ecosystems 7:1-12

Bohlen PJ, Scheu S, Hale CM, McLean MA, Migge S, Groffman PM, Parkinson D (2004b) Non-native invasive earthworms as agents of change in northern temperate forests. Front Ecol Environ 2:427-435

Bohlen PJ, Pelletier DM, Groffman PM, Fahey TJ, Fisk MC (2004c) Influence of earthworm invasion on redistribution and retention of soil carbon and nitrogen in northern temperate forests. Ecosystems $7: 13-27$
Brundrett MC, Kendrick B (1988) The mycorrhizal status, root anatomy and phenology of plants in a sugar maple forest. Can J Bot 66:1153-1173

Brussaard L (1999) On the mechanisms of interactions between earthworms and plants. Pedobiologia 43:880885

Burtelow AE, Bohlen PJ (1998) Influence of exotic earthworm invasion on soil organic matter, microbial biomass and denitrification potential in forest soils of the northeastern United States. Appl Soil Ecol 9:197202

Cain ML, Damman H, Muir A (1998) Seed dispersal and the Holocene migration of woodland herbs. Ecol Monogr 68:325-347

Canham CD, Finzi AC, Pacala SW, Burbank DH (1994) Causes and consequences of resource heterogeneity in forests: interspecific variation in light transmission by canopy trees. Can J For Res 24:337-349

Côté SD, Rooney TP, Tremblay J-P, Dussault CD, Waller DM (2004) Ecological impacts of deer overabundance. Ann Rev Ecol Syst 35:113-147

Cothrel SR, Vimmerstedt JP, Kost DA (1997) In situ recycling of urban deciduous litter. Soil Biol Biochem 29:295-298

Curry JP (1998) Factors affecting earthworm abundance in soils. In: Edwards A (ed) Earthworm ecology. St. Lucie Press, Boca Raton FL, pp 37-64

Curtis JT (1959) The vegetation of Wisconsin. University of Wisconsin Press, Madison WI, 657 pp

Dymond P, Scheu S, Parkinson D (1997) Density and distribution of Dendrobaena octaedra (Lumbricidae) in aspen and pine forests in the Canadian Rocky Mountains (Alberta). Soil Biol Biochem 29:265-273

Edwards CA, Bohlen P (1995) Biology and ecology of earthworms. Chapman and Hall, New York, 426 pp

Edwards CA (ed) (2004) Earthworm ecology, 2nd edn. CRC Press, Boca Raton FL, 456 pp

Francis R, Read DJ (1994) The contributions of mycorrhizal fungi to the determination of plant community structure. Plant Soil 159:11-25

Grime JP (1979) Plant strategies and vegetation processes. John Wiley and Sons, Chichester England, 222 pp

Gundale MJ (2002) Influence of exotic earthworms on the soil organic horizon and the rare fern Botrychium mormo. Conserv Biol 16:1555-1561

Hale CM, Frelich LE, Reich PB (2005a) Effects of European earthworm invasion on soil characteristics in northern hardwood forests of Minnesota. Ecosystems 8:911-927

Hale CM, Frelich LE, Reich PB (2005b) Exotic European earthworm invasion dynamics in northern hardwood forests of Minnesota, U.S.A. Ecol Appl 15:848-860

Hale CM (2004) Ecological consequences of exotic invaders: interactions involving European earthworms and native plant communities in hardwood forests. PhD Thesis, Department of Forest Resources, University of Minnesota, $169 \mathrm{pp}$

Harper JL, Williams JT, Sager GR (1965) The behavior of seeds in soil: the heterogeneity of soil surfaces and its role in determining the establishment of plants from seeds. J Ecol 53:273-286 
Hendriksen NB (1990) Leaf litter selection by detrivore and geophagous earthworms. Biol Fertil Soil 10:17-21

Heneghan L, Clay C, Brundage C (2002) Rapid decomposition of buckthorn litter may change soil nutrient levels. Ecol Restor 20:108-111

Heneghan L (2003) And when they got together... The impacts of eurasian earthworm and invasive shrubs on Chicago woodland ecosystems. Chic Wild J1:27-31

Horsley SB, Stout SL, deCalesta DS (2003) White-tailed deer impact on the vegetation dynamics of a northern hardwood forest. Ecol Appl 13:98-118

Johnson NC, Tilman GD, Wedin D (1992) Plant and soil controls on mycorrhizal fungal communities. Ecology 73:2034-2042

Jones CG, Lawton JH, Shachak M (1994) Organisms as ecosystem engineers. Oikos 69:373-386

Kostel-Hughes F (1995) The role of soil seed banks and leaf litter in the regeneration of native and exotic tree species in urban forests. PhD Thesis, Graduate Program in Ecology, Fordham University, Bronx, NY, $236 \mathrm{pp}$

Kubiena WL (1948) Entwicklungslehre des Bodens. Springer, Wien

Langmaid KK (1964) Some effects of earthworm invasion in virgin podsols. Can J Soil Sci 44:34-37

Leck MA, Parker VT, Simpson RL (eds) (1989) The ecology of soil seed banks. Academic Press, San Diego California, $462 \mathrm{pp}$

Lawrence B, Fisk MC, Fahey TJ, Suarez ER (2003) Influence of nonnative earthworms on mycorrhizal colonization of sugar maple (Acer saccharum). New Phytol 157:145-153

Lee KE (1985) Earthworms - Their ecology and relationships with soils and land use. Academic Press, Sydney, 411 pp

Lunt HA, Jacobson HGM (1944) The chemical composition of earthworm casts. Soil Sci 58:367-375

Marquis DA (1975) Seed storage and germination under northern hardwood forests. Can J For Res 5:478-484

McLean MA, Parkinson D (1997a) Changes in structure, organic matter and microbial activity in pine forest soil following the introduction of Dendrobaena octaedra (Oligochaeta, Lumbricidae). Soil Biol Biochem 29:537-540

McLean MA, Parkinson D (1997b) Soil impacts of the epigeic earthworm Dendrobaena octaedra on organic matter and microbial activity in lodgepole pine forest. Can J For Res 27:1907-1913

McLean MA, Parkinson D (1998a) Impacts of epigeic earthworm Dendrobaena octaedra on oribatid mite community diversity and microarthropod abundances in pine forest floor: a mesocosm study. Appl Soil Ecol 7:125-136

McLean MA, Parkinson D (1998b) Impacts of the epigeic earthworm Dendrobaena octaedra on microfungal community structure in pine forest floor - a mesocosm study. Appl Soil Ecol 8:61-75

McLean MA, Parkinson D (2000) Field evidence of the effects of the epigeic earthworm Dendrobaena octae$d r a$ on the microfungal community in pine forest floor. Soil Biol Biochem 32:351-360
Migge S (2001) The effect of earthworm invasion on nutrient turnover, microorganisms and microarthropods in Canadian aspen forest soil. PhD Thesis, Technische Universität Darmstadt, Darmstadt, Germany

Mladenoff DJ (1985) Dynamics of soil seed banks, vegetation and nitrogen availability in treefall gaps. $\mathrm{PhD}$ Thesis, Department of Botany, University of Wisconsin-Madison, 164 pp

Motzkin GD, Foster DR, Allen A, Harrod J, Boone R (1996) Controlling site to evaluate history: vegetation patterns of a New England sand plain. Ecol Monogr 66:345-365

Nielson GA, Hole FD (1963) A study of the natural processes of incorporation of organic matter into soil in the University of Wisconsin Arboretum. Wisc Acad Sci Arts Lett 52:213-227

Nielson GA, Hole FD (1964) Earthworms and the development of coprogenous $A_{1}$ horizons in forest soils of Wisconsin. Soil Sci Soc Am Proc 28:426-430

Nixon W (1995) As the worm turns. Am For 101:34-36

Newman EI, Reddell P (1988) Relationship between mycorrhizal infection and diversity in vegetation: evidence from the Great Smoky Mountains. Funct Ecol 2:259-262

Nordström S, Rundgren S (1974) Environmental factors and lumbricid associations in southern Sweden. Pedobiologia 14:1-27

Paré D, Bernier B (1989) Origin of phosphorous deficiency observed in declining sugar maple stands in the Quebec Appalachians. Can J For Res 19:24-34

Parkin TB, Berry EC (1994) Nitrogen transformations associated with earthworm casts. Soil Biol Biochem 26:1233-1238

Parkinson D, McLean MA, Scheu S (2004) Impacts of earthworms on the community structure of other biota in forest soils. In: Edwards CA (ed) Earthworm ecology, 2nd edn. CRC Press, Boca Raton FL, pp 241-259

Pastor J, Dewey B, Moen R, Mladenoff DJ, White MA, Cohen Y (1998) Spatial patterns in the moose-forestsoil ecosystem on Isle Royale, Michigan, USA. Ecol Appl 8:411-424

Pickett STA and McDonnell MJ (1989) Seed bank dynamics in temperate deciduous forest. In: Leck MA, Parker VT, Simpson RL (eds) The ecology of soil seed banks. Academic Press, San Diego CA, pp 123-145

Ponge JF, Delhaye L (1995) The heterogeneity of humus profiles and earthworm communities in a virgin beech forest. Biol Fertil Soil 20:24-32

Proulx N (2003) Ecological risk assessment of non-indigenous earthworm species. Prepared for U.S. Fish and Wildlife Service, International Affairs, Division of Scientific Authority by Minnesota Department of Natural Resources, St. Paul, Minnesota

Rogers R (1990) Quercus alba L. White oak. In: Burns RM and Honkala BH (Technical Coordinators), Silvics of North America, Volume 2, Hardwoods, United States Department of Agriculture, Forest Service, Agriculture Handbook 654, Washington DC, pp 605-613 
Sander I.L (1990) Quercus rubra L. Northern red oak. In: Burns RM and Honkala BH (Technical Coordinators), Silvics of North America, Volume 2, Hardwoods, United States Department of Agriculture, Forest Service, Agriculture Handbook 654, Washington DC, pp 727-733

Schaefer M (1991) Animals in European temperate deciduous forest. In: Röhrig E, Ulrich B (eds) Temperate deciduous forests. Ecosystems of the world 7. Elsevier, Amsterdam, pp 503-525

Scheu S (1987) The influence of earthworms (Lumbricidae) on the nitrogen dynamics in the soil litter system of a deciduous forest. Oecologia 72:197-201

Scheu S (2003) Effects of earthworms on plant growth: patterns and perspectives. Pedobiologia 47:846-856

Scheu S, Parkinson D (1994a) Effects of invasion of an aspen forest (Canada) by Dendrobaena octaedra (Lumbricidae) on plant growth. Ecology 75:2348-2361

Scheu S, Parkinson D (1994b) Effects of earthworms on nutrient dynamics, carbon turnover, and microorganisms in soil from cool temperate forests of the Canadian Rocky Mountains - laboratory studies. Appl Soil Ecol 1:113-125

Shaw C, Pawluk S (1986) The development of soil structure by Octolasion tyrtaeum, Aporrectodea turgida and Lumbricus terrestris in parent materials belonging to different textural classes. Pedobiologia 29:327-339
Suarez ER, Fahey TJ, Groffman PM, Bohlen PJ, Fisk MC (2004) Effects of exotic earthworms on soil phosphorous cycling in two broadleaf temperate forests. Ecosystems 7:28-44

Sydes C, Grime JP (1981) Effects of tree leaf litter on herbaceous vegetation in deciduous woodland: an experimental investigation. J Ecol 69:249-262

Syers JK, Sharpley AN, Keeney DR (1979) Cycling of nitrogen by surface casting earthworms in pasture ecosystems. Soil Biol Biochem 11:181-185

Tiunov AV, Hale CM, Holdsworth AR, Perel TS (2006) Invasion patterns of lumbricidae into the previously earthworm-free areas of north-eastern Europe and the western Great Lakes Region of North America. Biological Invasions (in press)

Tomlin AD, Shipitalo MJ, Edwards WM, Protz R (1995) Earthworms and their influence on soil structure and infiltration. In: Hendrix PF (ed) Earthworm ecology and biogeography in North America. CRC Press, Boca Raton FL, pp 159-184

van der Heijden MGA, Klironomos JN, Ursic M, Moutoglis P, Streitwolfengel R, Boller T, Wiemken A, Sanders IR (1998) Mycorrhizal fungal diversity determines plant biodiversity, ecosystem variability and productivity. Nature 396:69-72 